\title{
Biochemical and Production of Rhubarb Under Growing Technological Factors
}

\author{
ALEXANDRU COJOCARU ${ }^{1}$, NECULAI MUNTEANU ${ }^{1}$, BRINDUSA ALINA PETRE ${ }^{2}$, TEODOR STAN ${ }^{1}$, GABRIEL CIPRIAN TELIBAN ${ }^{1}$, \\ CATALIN VINTU', VASILE STOLERU'* \\ 'University of Agriculture Sciences and Veterinary Medicine, 3 M. Sadoveanu, 700440, lasi, Romania \\ 2 University Al.I.Cuza, 11 Carol I Blvd., 700506, Iasi, Romania
}

The aim of the present study was to assess the influence of two varieties of rhubarb (Glanskin's Perpetual and De Moldova) and two densities, 10.000 and $13.300 \mathrm{pl} / \mathrm{ha}$ on the content of macro (K, Ca, P, Mg, Fe and S), micro-elements (Al, Si and Mn), organic acids (tartaric, oxalic, citric, malic and ascorbic) and total production. The content of oxalic acid in the four versions ranged from $2.3 \mathrm{mg} / \mathrm{mL}$ juice in the case of Glanskin's perpetual cultivation, with the density of $13.300 \mathrm{pl} / \mathrm{ha}$ at $3.8 \mathrm{mg} / \mathrm{mL}$ in the case of the Moldova variety at the same density. The content of tartaric acid varied in wide limits from $1.75 \mathrm{mg} / \mathrm{mL}$ juice to 6.5 $\mathrm{mg} / \mathrm{mL}$ juice. The content of macro-elements varied within wide limits, the report being: $\mathrm{Fe}>\mathrm{K}>\mathrm{Mg}>\mathrm{S}$ $>P>C a$. The largest production was obtained at the variety De Moldova with density of $13.300 \mathrm{pl} / \mathrm{ha}$.

Keywords: rhubarb, macro and microelements, organic acids, technological factors

Rhubard (Rheum rhabarbarum L.) is a perennial vegetable species [1], cultivated only for its petiole [2], its leaves being toxic due to their content of oxalic acid [3]. In the world, this vegetable species is less known, being spread out mainly in the Asian countries, for medical purposes [4]. In Europe, it is cultivated more in Germany, France and England [5, 6].

Rhubarb contains main active components (chrysophanol $\left[\mathrm{C}_{15} \mathrm{H}_{20} \mathrm{O}_{1}\right]$, aloe-emodin $\left[\mathrm{C}_{15} \mathrm{H}_{10} \mathrm{O}_{5}\right]$, rhein $\left[\mathrm{C}_{15} \mathrm{H}_{8} \mathrm{O}_{6}\right]$, emodin $\left[\mathrm{C}_{15} \mathrm{H}_{10} \mathrm{O}_{5}\right]$ and physcion $\left.\left[\mathrm{C}_{16}^{5} \mathrm{H}_{12} \mathrm{O}_{5}\right]\right)$, with pharmacodynamic effects [7].

The production and composition of petioles is clearly influenced by the technology applied to the crop, especially by the variety, the planting distance and the nutritional regimen $[8,9]$.

Organic acids play a biochemical role in maintaining the nutritional value and the quality of a vegetable species, and therefore they are among the frequently quantified compounds [10].

The major acid present in the rhubarb petioles is the malic acid, followed by oxalic acid and citric acid [11, 12].

Rhubarb juice can be used as an agent to blanch fruits [13] as well as an antioxidant to preserve fruits [14]. Products made of rhubarb have a favorable taste due to a high content of organic acids and rhubarb stalks taste best in early spring when they are ripe $[15,16]$.

Previous studies have shown that the root fresh weight and root dry weight increased significantly at the wilting stage following treatment with $90 \mathrm{~kg} / \mathrm{ha} \mathrm{P}_{2} \mathrm{O}_{5}$ (100\% and $59 \%$, respectively) and $75 \mathrm{~kg} / \mathrm{ha} \mathrm{K}_{2} \mathrm{O}$ ( $43 \%$ and $41 \%$, respectively) compared to the control ${ }^{2}[17]$.

The high content of potassium in rhubarb juice ranges from 2814 to $4000 \mathrm{mg} / \mathrm{L}$. Also, magnesium concentrations were comparably high and ranged from 53 to $136 \mathrm{mg} / \mathrm{L}$. In contrast to other vegetables, rhubarb juice does not contain calcium in high levels, because the exceeding oxalic acid precipitated rapidly with calcium and form insoluble calcium oxalate. Particularly, the natural sodium values are very high in comparison to other fruit and vegetable juices (5-202 $\mathrm{mg} / \mathrm{L}$ ). The antioxidant capacity varied from 2.6 to $25 \mathrm{mmol} / \mathrm{L}$ Trolox [18, 19].
The data present in the literature regarding the establishment of the rhubarb crop highlight the fact that in the first year after the crop is established, there may be obtained productions of $0.7 \mathrm{~kg} / \mathrm{pl}$.at a density of $8.000 \mathrm{pl} /$ ha [20]. At densities of $13.300 \mathrm{pl} / \mathrm{ha}$, the Victoria cultivar has obtained overall productions of $46.64 \mathrm{t} / \mathrm{ha}$, comparatively with the density of $8.000 \mathrm{pl} / \mathrm{ha}$, where obtained production was of $21.72 \mathrm{t} / \mathrm{ha}$ [3]. By the tissue culture, in the first year after the crop was established, early yield achieved 11.2 t/ha and plants accounted for $25 \%$ of the total petiole yield [21].

The non-destructive methodology based on X-ray fluorescence (EDXRF) has been applied for the determination of some major and minor elements ( $\mathrm{K}, \mathrm{Ca}$, $\mathrm{Fe}, \mathrm{Mn}, \mathrm{Cu}$ and $\mathrm{Zn}$ ) in different rhubarb species: Atriplexhortensis, Rumexpatienta, Lactuca sativa, Spinacea oleracea. Atriplexhortensis and Rumexpatientia species presented higher value of potassium $(K)$ content, ranged from 2.9 to $4.75 \%$. The highes tiron (Fe) concentrations were 1002.5 and 952.05 ppm from Lactuca sativa and Rumexpatientia species and calcium (Ca) concentration ranges from 1.2 to $2.15 \%$ with the highest value attributed to Spinacea oleracea species [22].

The highest oxalate content in leaves and stems was found in plants from these families. Total oxalate content ranged from 143 to $232 \mathrm{mg} / 100 \mathrm{~g}$ in roots, and 874 to 1959 $\mathrm{mg} / 100 \mathrm{~g}$ in leaves and stems. As reported in the literature, patients with calcium oxalate stone disease should be advised to avoid these oxalate rich foods [23].

In this context, the aim of the study was to assess the influence of two rhubarb varieties and two densities on the content of macro and microelements, organic acids and total yield of production.

\section{Experimental part}

The experiment was carried out in the research station at Ion Ionescu de la Brad University of Agricultural Sciences and Veterinary Medicine of lai, on a rhubarb crop established by seedlings in 2013 . The cambic chernozem soil is characterized by a medium fertility, with $3 \%$ organic matter, $31 \%$ of clay and $\mathrm{pH}=6.6$.

\footnotetext{
*email: vstoleru@uaiasi.ro
} 
During the experimental year, in the vegetation period, the average temperature was $18^{\circ} \mathrm{C}$, the precipitation was $517.8 \mathrm{~mm}$ and the relative air humidity was $67 \%$ [24].

\section{Experimental design}

To achieve the main goal of this research, a bi-factorial trial was represented by cultivar ( $\mathrm{cv}$.) with two graduations, "Glaskin's perpetual" (GP) and "Moldova Local population" (LP) and plant density, with two graduations, 13.300 and $10.000 \mathrm{pl} / \mathrm{ha}$. The trial was organized in a split plot design, with three replicates, and each plot had a surface of 16.50 $\mathrm{m}^{2}$.

The determinations were made according to national and international standards in accordance with International Organization for Standardization (ISO) and Official Methods of Analysis of AOAC INTERNATIONAL, 20th Edition (2016). AOAC Standards Guidelines \& References -AOAC International. AOAC offers the official analysis methods of AOAC INTERNATIONAL (OMA) Official Methods of Analysis of AOAC INTERNATIONAL.

\section{Determination of macroelements and microelements}

In order to determine the concentration of essential elements from the studied samples, the atomic absorption method was used (Contra 300), Analytik Jena [25, 26]. The component parts of the variants used in the study were dried in a drying oven at $105^{\circ} \mathrm{C}$, and then there was measured between 0.5 and $1 \mathrm{~g}$ per each sample, and finally they were subjected to a process of disaggregation (digestive or mineralization) for bringing them into solution $[27,28]$.

\section{Determination of organic acids}

The analyses were carried out in collaboration with, Chemistry \& Biochemistry Laboratory of Banat's University, using methods previous reported [29,30]. Juice extract samples were obtained from each petiole variant. The samples were extracted in a Soxhlet-type apparatus in which the solvent is provided by boiling the extract. This method is based on the difference between the boiling points of the solvent and the extracted analyses [31, 32].

The aqueous extract obtained was centrifuged at 3000 rpm for 10 minutes, and the supernatant was diluted in 1:50 ratio in order to determine the citric acid and in a 1:5 ratio in order to determine the oxalic, citric, malic, tartaric and ascorbic acids. The dilutions were filtered prior to photocolorimetric determination of the acid concentration, analyzing two samples in duplicate. A standard mixed solution was prepared, containing $1000 \mathrm{mg} / \mathrm{L}$ citric acid, $2000 \mathrm{mg} / \mathrm{L}$ malic acid, $300 \mathrm{mg} / \mathrm{L}$ oxalic and ascorbic acid and $700 \mathrm{mg} / \mathrm{L}$ tartaric acid [33]. The standard solution and the corresponding dilutions were prepared with distilled water and were kept at a low temperature $\left(4^{\circ} \mathrm{C}\right)$ in a dark place. The organic acids from the studied samples were separated and determined with the aid of the absorbance, and then quantified with calibration graphs. For the ascorbic acid, the wavelength $\lambda=254 \mathrm{~nm}$ was used, respectively $\lambda$ $=214 \mathrm{~nm}$ for the other organic acids [34, 35].

\section{Determination of total production}

The harvesting was done manually, on a weekly basis, the petioles having a diameter ranging between 1.5-2.5 $\mathrm{cm}$ and the length of $30-35 \mathrm{~cm}$. No more than $1 / 3$ of petioles were harvested, in order to avoid weakening the plants as reported in previous studies [36].

\section{Data processing and statistical analyses}

The experimental data processing was carried out using statistical methods. Standard deviation ( \pm SD) was calculated for each data series as an indicator of dataset scatter $(n=3)$. The significance of acid content and yield, due to cultivar $x$ density combinations was established by ANOVA [37, 38], based on the Fisher test. The differences among the average values for each experimental variant were compared by using the Student test and the least significant difference (LSD) test at $p<0.05$ probability level, computed by the SPSS version 20.

\section{Results and discussions}

The results obtained in the case of macroelements by spectrophotometry with atomic absorption are presented in table 1 . The main content of macroelements is represented by Fe, followed by K and Mg. According to the specialized literature, the $\mathrm{Ca}$ content is relatively reduced, because it precipitates in the presence of oxalates [39].

The content of $\mathrm{Fe}, \mathrm{K}, \mathrm{Mg}, \mathrm{P}$ and $\mathrm{Ca}$ varies within small limits depending on the variety, with the exception of $S$, where in the case of the GP cultivar, the content was of $0.53 \mathrm{~g} / 100 \mathrm{~g} \mathrm{fw}$ comparatively with LP, where the average was of $0.70 \mathrm{~g} / 100 \mathrm{~g} \mathrm{fw}$. The content of $\mathrm{K}, \mathrm{Ca}, \mathrm{P}$ and $\mathrm{Fe}$ is much higher in the case of higher densities, comparatively with $\mathrm{Mg}$ and $\mathrm{S}$, which are accumulated in higher quantities, at more reduced densities.

The results obtained in the case of microelements ( $\mathrm{Si}$, $\mathrm{Al}$ and $\mathrm{Ti}$ ), studied by spectrophotometry with atomic absorption are presented in table 2. According to specialized literature, a high content of $S i$ is also present in the case of the species from the Polygonaceae family, such as the sorrel, where this element varies between 1.8 and $17 \mathrm{~g} / 100 \mathrm{~g} \mathrm{fw}$ [40]. The content of Si and Ti varies within very small limits, depending on the variety and density.

Manganese is an element that varies in the petiole within higher limits depending on the variety, so in the GP cultivar, the average content is of $0.34 \mathrm{~g} / 100 \mathrm{~g}$ fw comparatively with the LP, where the average content was of $0.24 \mathrm{~g} / 100$ $\mathrm{g}$ fw.

The aluminum content varies in the plant's petiole, both depending on the variety and on the density, so the highest

\begin{tabular}{|c|c|c|c|c|c|c|}
\hline \multirow{2}{*}{ Variant } & \multicolumn{6}{|c|}{ Macronutrients contents } \\
\hline & $\mathrm{K} w \mathrm{t} \%$ & Ca wt $\%$ & P wt $\%$ & $\mathrm{Mg} w t \%$ & Fe wt $\%$ & S wt $\%$ \\
\hline$V_{1}$ & $1.93 \pm 0.01$ & $0.52=0.00$ & $0.53 \pm 0.01$ & $1.03 \pm 0.01$ & $5.19 \pm 0.02$ & $0.54 \pm 0.01$ \\
\hline$V_{2}$ & $1.84 \pm 0.01$ & $0.54 \pm 0.01$ & $0.54 \pm 0.01$ & $1.11=0.01$ & $4.61=0.01$ & $0.53 \pm 0.00$ \\
\hline$V_{3}$ & $1.85 \pm 0.01$ & $0.49 \pm 0.00$ & $0.52 \pm 0.00$ & $1.13 \pm 0.01$ & $4.77 \pm 0.04$ & $0.69 \pm 0.01$ \\
\hline$V_{4}$ & $1.94 \pm 0.01$ & $0.51=0.01$ & $0.60 \pm 0.01$ & $1.00 \pm 0.06$ & $5.20=0.05$ & $0.71 \pm 0.01$ \\
\hline$\overline{\mathbf{x}}$ & $1.89 \pm 0.01$ & $0.51=0.01$ & $0.55 \pm 0.01$ & $1.07 \pm 0.02$ & $4.94 \pm 0.03$ & $0.62 \pm 0.01$ \\
\hline
\end{tabular}

Table 1

CONTENT OF

MACROELEMENTS IN THE RHUBARB PETIOLE $(n= \pm 3)$ 


\begin{tabular}{|c|c|c|c|c|}
\hline \multirow{2}{*}{ Variant } & \multicolumn{4}{|c|}{ Micronutrients contents } \\
\hline & $\mathrm{Al}(\mathrm{ppm})$ & $\mathrm{Si}(\mathrm{ppm})$ & $\mathrm{Ti}$ (ppm) & $\mathrm{Mn}(\mathrm{ppm})$ \\
\hline$V_{1}$ & $7.40 \pm 0.01$ & $28.48 \pm 0.46$ & $0.48 \pm 0.01$ & $0.35 \pm 0.01$ \\
\hline$V_{2}$ & $7.52 \pm 0.01$ & $28.80 \pm 0.81$ & $0.42 \pm 0.01$ & $0.33 \pm 0.01$ \\
\hline$V_{3}$ & $7.46 \pm 0.03$ & $28.74 \pm 0.15$ & $0.43 \pm 0.02$ & $0.26 \pm 0.02$ \\
\hline$V_{4}$ & $6.79 \pm 0.09$ & $28.94 \pm 0.81$ & $0.47 \pm 0.02$ & $0.22 \pm 0.02$ \\
\hline$\overline{\mathbf{x}}$ & $7.29 \pm 0.03$ & $28.74 \pm 0.56$ & $0.45 \pm 0.01$ & $0.29 \pm 0.02$ \\
\hline $\begin{array}{l}\text { V1-Gla } \\
\text { Local po: } \\
\text { pl/ha. }\end{array}$ & $\begin{array}{l}\text { rpetual x } 1 \\
\text { e Moldova }\end{array}$ & $\begin{array}{l}\text { D.ha; } V_{2}-\mathrm{C} \\
00 \mathrm{pl} / \mathrm{ha} ; \mathrm{V}_{4}\end{array}$ & $\begin{array}{l}\text { I's perpetua } \\
\text { l population }\end{array}$ & $\begin{array}{l}00 \mathrm{pl} . \mathrm{ha} ; \mathrm{V}_{3} \\
\text { oldov } \mathrm{x} 10.000\end{array}$ \\
\hline
\end{tabular}

Table 2

CONTENT OF MICROELEMENTS IN THE RHUBARB PETIOLE $(n= \pm 3)$ content was obtained in the GP cultivar, at the lowest density, namely $7.52 \mathrm{~g} / 100 \mathrm{~g} \mathrm{fw}$.

The high content of microelements in rhubarb, comparatively with other vegetable species is also determined by the fact that the rhizome of this vegetable species explores a large volume of soil, therefore the content is higher in the petioles of this plant, compared with other vegetables [41].

The main acids analyzed from the aqueous extract of rhubarb were: the malic, citric, tartaric, ascorbic and oxalic acids. The malic acid is the most important acid from the aqueous extract of rhubarb, with an average content of $6.79 \mathrm{mg} / \mathrm{mL}$ juice. According to the data presented in Table3, this acid does not vary in the petiole depending on the cultivar and density.

The tartaric acid varies both depending on the variety and on the density. Therefore, then content of tartaric acid varies from $2.77 \mathrm{mg} / \mathrm{mL}$ juice in the GP cultivar, up to 5.04 $\mathrm{mg} / \mathrm{mL}$ juice in the LP cultivar. Tartaric acids is accumulated in higher quantities in the case of more reduced densities, so, for $10.000 \mathrm{pl} . / \mathrm{ha}$, the content was of $4.22 \mathrm{mg} / \mathrm{mL}$ juice, comparatively with the higher density, where the content was of $3.59 \mathrm{mg} / \mathrm{mL}$.
The same trend regarding the higher level of oxalic, citric and ascorbic acids may be highlighted in the case of the GP and LP varieties, where the population De Moldova presents higher content levels of organic acids.

Similar data is presented in other references as well, where the local populations, well adapted to the climatic conditions, accumulate higher quantities of acids [42]. The content of tartaric and ascorbic acids is higher in the case of more reduced densities, $5.20 \mathrm{mg} / \mathrm{mL}$ juice for $L P$, and $4.38 \mathrm{mg} / \mathrm{mL}$ juice for LP respectively.

The production obtained in the case of the rhubarb cultivars is influenced both by the variety and the density. The total production has varied between 27.20 t/ha in the case of the GP cultivar, at a reduced density, up to $39.02 \mathrm{t} /$ ha in the case of the LP cultivar, at a high density, the differences obtained in this case compared to the average, being processed statistically $(p<0.01)$ (table 4$)$.

In the case of the GP variety, the production was of 30.00 t/ha, 35.15 t/ha respectively, in the case of the LP cultivar. Higher productions are also obtained in the case of high densities, respectively 35.91 t/ha, comparatively with the density of $10000 \mathrm{pl} / \mathrm{ha}$ where the total production was of 29.24 tha.

Table 3

CONTENT OF ORGANIC ACIDS IN THE RHUBARB PETIOLE $(n= \pm 3)$

\begin{tabular}{|c|c|c|c|c|c|}
\hline Variant & $\begin{array}{l}\text { Tartaric acid } \\
\text { (mg/mLsuc) }\end{array}$ & $\begin{array}{l}\text { Oxalic acid } \\
\text { (mg/mLsuc) }\end{array}$ & $\begin{array}{c}\text { Citric acid } \\
(\mathrm{mg} / \mathrm{mL} \text { suc })\end{array}$ & $\begin{array}{c}\text { Malic acid } \\
\text { (mg/mLsuc) }\end{array}$ & $\begin{array}{c}\text { Ascorbic acid } \\
\text { (mg/mLsuc) }\end{array}$ \\
\hline$V_{1}$ & $2.30=0.04$ & $2.56 \pm 0.10$ & $5.34 \pm 0.02$ & $6.70 \pm 0.06$ & $3.39 \pm 0.03$ \\
\hline $\mathrm{V}_{2}$ & $3.24 \pm 0.03$ & $3.40 \pm 0.06$ & $5.01=0.04$ & $6.77 \pm 0.08$ & $3.59=0.04$ \\
\hline$V_{3}$ & $4.88 \pm 0.05$ & $3.77 \pm 0.07$ & $4.65 \pm 0.04$ & $6.83 \pm 0.06$ & $3.87 \pm 0.03$ \\
\hline$V_{4}$ & $5.20=0.05$ & $3.43 \pm 0.04$ & $4.41=0.04$ & $6.87 \pm 0.03$ & $4.38 \pm 0.03$ \\
\hline$\overline{\mathbf{x}}$ & $3.91=0.04$ & $3.29 \pm 0.06$ & $4.85 \pm 0.04$ & $6.79 \pm 0.05$ & $3.81 \pm 0.03$ \\
\hline
\end{tabular}

Table 4

INFLUENCE OF CULTIVAR X DENSITY FACTORS ON RHUBARB YIELD $(n= \pm 3)$

\begin{tabular}{|c|c|c|c|c|}
\hline Variant & $\begin{array}{l}\text { Total yield } \\
\text { (t/ha) }\end{array}$ & $\%$ to the average & $\begin{array}{l}\text { Difference to } \\
\text { average ( } t / \mathrm{ha} \text { ) }\end{array}$ & $\begin{array}{l}\text { Significance of } \\
\text { differences }\end{array}$ \\
\hline$V_{1}$ & $32.79 \pm 0.19$ & 100.68 & 0.22 & $\mathrm{~ns}$ \\
\hline$V_{2}$ & $27.20 \pm 0.36$ & 83.51 & -5.37 & 00 \\
\hline$V_{3}$ & $39.02 \pm 0.30$ & 119.80 & 6.45 & $8 \%$ \\
\hline$V_{4}$ & $31.28 \pm 0.67$ & 96.04 & -1.29 & $\mathrm{~ns}$ \\
\hline$\overline{\mathrm{X}}$ & $32.57 \pm 0.38$ & 100.00 & 0.00 & - \\
\hline \multicolumn{5}{|c|}{$\begin{array}{l}\text { LSD } 5 \%=3.18 \text { tha; LSD } 1 \%=4.82 \text { tha; LSD } 0,01 \%=7.74 \text { tha; } V_{1}-\text { Glanskin's perpetual x } 13.300 \\
\text { pl/ha; } V_{2}-\text { Glanskin's perpetual x } 10.000 \mathrm{pl} / \text { ha; } V_{3}-\text { Local population; Ns - nonsignificant; } 00- \\
\text { negative significantly different; } * * \text { - positive significantly distinct }\end{array}$} \\
\hline
\end{tabular}




\section{Conclusions}

The macroelements analyzed in the rhubarb petiole were found to be in the following series $\mathrm{Fe}>\mathrm{K}>\mathrm{Mg}>\mathrm{S}>$ $\mathrm{P}>\mathrm{Ca}$. Among the microelements, the highest determined content was represented by Si and Al, higher at a lower density, in the case of Si, with an average content of 28.87 $\mathrm{g} / 100 \mathrm{~g} \mathrm{fw}$, comparatively with Al, where the highest content was obtained at a higher density of an average value of $7.42 \mathrm{~g} / 100 \mathrm{~g} \mathrm{fw}$.

The organic acids present in the aqueous extract of rhubarb vary within wide limits, depending on the nature of each acid and the content is influenced mainly by the variety and less by the density. The largest production of rhubarb petioles was obtained at the variety De Moldova with a density of $13,300 \mathrm{pl} / \mathrm{ha}$. Our studies proved the micro and macro elemental composition of different varieties of rhubarb, a well known traditional Chinese herb, with antiinflammatory and antimicrobial properties.

\section{References}

1.CIOFU, R., POPESCU, V., CHILOM, P., APAHIDEAN, S., HORGOS, A., BERAR, V., LAUER, K.F., ATANASIU, N., Vegetable Growing Treated, Ed. Ceres, Bucuresti, 2003, p. 1027.

2.STAN, N., MUNTEANU, N., STAN, T., Vegetable growing, 3, Ed. Ion Ionescu de la Brad, lasi, 2003, p. 235.

3.STOLERU, V., MUNTEANU, N., STAN, T., IPATIOAIE, C., COJ OCARU, A., BUTNARIU, M., Romanian Biotechnological Letters, 2018. DOI:10.26327/RBL2017.98.

4.COJ OCARU, A., MUNTEANU, N., STOLERU, V., IPATIOAIEI, C.D., Scientific Papers USAMV lasi -Horticulture series, 59, no. 2, 2016, p. 193.

5.COJ OCARU, A., MUNTEANU, N., STOLERU, V., IPATIOAIEI, C.D., Scientific Papers USAMV lasi - Horticulture series, 59, no. 2, 2016, p. 177.

6.INDREA, D., APAHIDEAN, S., APAHIDEAN, M., MANIUTIU, D., SIMA, R., Vegetables crop, Ed. Ceres, Bucuresti, 2012, p. 144.

7. INTAO, X., YONGLI, S., LIMING, Y., QUANWEI, Y., CHUNYAN, LI., XINGYY, C., YUN, J ., Spectrochimica Acta, 205, 2018, p. 419.

8.COJ OCARU, A., Research on the using of intensivemethods in rhubarb (Rheum rhabarbarumL.) crop, PhD Thesis, USAMV Iasi, 2017, p. 75.

9.CREAGER, RA., Crop Protection, 8, no. 6, 1989, p. 443.

10.KACANIOVA, M., KNAZOVICKA, V., MELICH, M., FIKSELOVA, M., MASSANYI, P., STAWARZ, R., HASCIK, P., PECHOCIAK, T., KUCZKOWSKA, A., PUTALA, A.J ., Environ. Sci. Health, Part A: Environ. Sci. Eng., 44, no.4, 2009, p. 414.

11.WILL, F., DIETRICH, H., LWT - Food Science and Technology, $\mathbf{5 0}$ no. 2, 2013, p. 673.

12.BAKKER, J.J ., SCHROEN, G., ROELANDS, C., Groentenen Fruit, 41, no. 15, 1985, p. 62.

13.SON, S.M., MOON, K.D., LEE, C.Y., J. Food Sci., 65, no.7, 2000, p. $1288-1289$.

14.WOJ DY£O, A., OSZMAN 'SKI, J., BOBER, I., Eur. Food Res. Technol., 227, 2008, p. 1043-1051.

15.SAfATA, A., NAJ DA, A., KUZYK, K., Veg. Crop Res. Bull., 55, 2001, p. 109.
16.RAFAL, N., JACEK, S., AGNIESZKA, S., ZBIGNIEW, K., KAZIMIERZ, Z., AGNIESZKA, S., JAKUB, W., J. Food Engineering, 166, 2015, p. 370. 17.NA, S., YULEI, C., WENHUA, X., XIAOHUI, Z., LUCUN, Y., Industial crops and products, 107, 2017, p. 312.

18.FRANK, W., HELMUT, D., Deutsche Lebensmittel-Rundschau, 112, no. 9, 2016, p. 409.

19.FRANK, W., HELMUT, D., Lwt-Food Sci and Tech., 50, no. 2, 2013, p. 673.

20.ANDRZEJ, S., DANUTA, K., Acta Sc Polonorum-HortorumCultus, 12, no. 1, 2013, p. 115.

21.LEPSE, L., Acta Horticulturae, 812, 2009, p. 265.

22.STIHI, C., POPESCU, V.I., GHEBOIANU, A., FRONTASYEVA, M., ENE, A., DIMA, G., BUTE, O., CIMPOCA, GH.V., STIHI, V., OROS, D.C., DINU, S., VOICU, M., Journal of Science and Arts, 9, no. 2, 2008, p. 331.

23.SIENER, R., HONOW, R., SEIDLER, A., VOSS, S., HESSE, A., Food Chemistry, 98, no. 2, 2006, p. 220.

24.*** AgroExpert weather data from V. Adamachi Weather Station lasi, 2016.

25.PUTNOKY, S., CAUNII, A., BUTNARIU, M., Chemistry central journal, 7, no. 21, 2013, p. 1.

26.VLASE, L., BENEDEC, D., HANGANU, D., DAMIAN, G., CSILLAG, I., SEVASTRE, B., MOT, A.C., SILAGHI-DUMITRESCU, R., TILEA, I., Molecules, 19, no. 5, 2014, p. 5490.

27.BUTNARIU, M., CAUNII, A., PUTNOKY, S., Chem Cent J ., 6, no. 1, p. 1.

28.BUTU, M., BUTNARIU, M., RODINO, S., BUTU, A., Digest journal of nanomaterials and biostructures, 9, no. 3, 2014, p. 935.

29.BUTU, M., RODINO, S., BUTU, A., BUTNARIU. M. Digest journal of nanomaterials and biostructures, 9, no. 2. 2014, p. 519.

30.BUTNARIU, M., RODINO, S., PETRACHE, P., NEGOESCU, C., BUTU, M., Digest journal of nanomaterials and biostructures, 9, no. 2, 2014, p. 745.

31.SAMFIRA, I., BUTNARIU, M., RODINO, S., BUTU, M., Digest J ournal of Nanomaterials and Biostructures, 8, no. 4, 2013, p.1679.

32.BUTNARIU, M., Annals of agricultural and environmental medicine, 21, no. 1, 2014, p. 11.

33.OUIS, N., HARIRI, A., Banats J. Biotechnol., 8, no. 16, 2017, p. 93. 34.VASILEVA, V., Banats J Biotechnol, 6, no. 11, 2015, p. 100.

35.HAMZA, B., ASMAA, B., BOUMEDIENE, M., Banats J Biotechnol, 8, no. 15,2017, p. 78.

36.IPATIOAIE, D.C., Research regarding the improvement of the technology used in the establishment of the rhubarb crop (Rheum rhabarbarum L.), PhD Thesis, USAMV lasi, 2017, p. 109.

37.LEONTE, C., SIMIONIUC, V.,Methods and techniques used in agronomic research, Ed.Ion Ionescu from Brad, lasi, 2018, p. 195. 38.ZOBEL, R.W., WRIGHT, M.J., GAUCH, H.G., Agronomy J ournal, 80, no. 3,1988, p. 388.

39.GAVEDA, M., Polish J. of Environ. Stud., 18, no. 2, 2009, p. 213.

40.TUAZON-NARTEA, J., SAVAGE, G., Food and Nutrition Sciences, 4, no. 8,2013, p. 838.

41.J HAM, G.N., FERNANDES, S.A., GARCIA, C.F., DA SILVA, A.A., Phytochemical Analysis, 13, no. 2, 2002, p. 99.

42.DIMITRIU, D.C., STOLERU, V., CORCIOVA, A., VLASE, L., STAN, T., J ITAREANU, A., MUNTEANU, N., ROTARU, L., PATRAS, A., Environmental Engineering and Management J ournal, 15, no. 8, 2016, p. 1841.

Manuscript received: 14.01 .2019 